\title{
ANALISIS PERUBAHAN PENDAPATAN PT TELEKOMUNIKASI INDONESIA TBK. TAHUN 2017 DAN 2018
}

\author{
Eni Suasri ${ }^{1}$, Dahlia ${ }^{2)}$ \\ 1) 2) Politeknik Negeri Tanah Laut \\ Jalan Ahmad Yani Km. 06 Desa Panggung, Kalimantan Selatan 70815 \\ ${ }^{1)}$ eni@politala.ac.id \\ ${ }^{2)}$ d1317002.akt@politala.ac.id
}

Diterima : 08 November 2019. Disetujui 28 Juni 2020. Dipublikasikan : Juni 2020

\begin{abstract}
Abstrak
Penelitian ini bertujuan untuk menganalisis perbandingan naik dan turunnya suatu laporan keuangan yang terjadi pada PT Telekomunikasi Indonesia Tbk. selama tahun 2017 dan 2018. Data penelitian ini diperoleh dari Bursa Efek Indonesia (BEI) yang dibanalisa menggunakan metode analisis perubahan pendapatan laba kotor. Hasil penelitian diketahui bahwa keuangan perusahaan PT Telekomunikasi Indonesia Tbk selama dua tahun terakhir cenderung mengalami penurunan disebabkan oleh faktor penjualan memiliki nilai yang lebih kecil dibandingkan perubahan laba kotor karena semakin tingginya persaingan dan semakin banyakanya pelaku usaha sejenis dalam bidang industri telekomunikasi yang mengakibatkan meningkatnya kegiatan, periklanan, penurunan harga dan munculnya berbagai ragam layanan yang ditawarkan operator. Analisis laporan keuangan dapat meberikan gambaran yang jelas tentang keadaan keuangan dan hasil usaha perusahaan, informasi tersebut dapat digunakan dalam pembuatan suatu keputasan bisnis dan investasi.
\end{abstract}

Kata kunci: Laba Kotor, Laporan Keuangan, PT Telekomunikasi Indonesia Tbk

\begin{abstract}
This study aims to analyze the comparison of the ups and downs of a financial statement that occurred at PT Telekomunikasi Indonesia Tbk. during 2017 and 2018. Data was obtained from the Indonesia Stock Exchange (IDX) and then analyzed using income change methods againt gross profit analysis.. From the results of the study note that the financial company PT Telekomunikasi Indonesia Tbk. over the past two years it has tend to decline. The decline was due to the sales faktor which had a smaller value than the change in gross profit due to higher competition and the increasing number of similar business actors in the telecommunications industry which resulted in increased activity, advertising, price reduction and the emergence of various services offered by operators. Analysis of financial statements can provide a clear picture of the financial condition and results of operations of the company, the information can be used in making a business and investment decision.
\end{abstract}

Keywords: Gross Profit, Financial Statements, PT Telekomunikasi Indonesia Tbk

\section{PENDAHULUAN}

Sektor jasa telekomunikasi dan jaringan di Indonesia yang mampu bertahan dalam kondisi persaingan jika tidak didukung dengan financial yang kuat. PT Telekomunikasi Indonesia adalah perusahaan BUMN (Badan Usaha Milik Negara) yang bergerak di bidang jasa layanan telekomunikasi dan jaringan di wilayah Indonesia. Sejak awal berdiri PT Telekomunikasi Indonesia Tbk. Ini sudah melakukan penyusunan laporan keuangan yang rutin. Laporan keuangan yang disusun oleh PT Telekomunikasi Indonesia Tbk. meliputi, Laporan Posisi Keuangan, laporan laba-rugi, laporan ekuitas, laporanarus kas dan penghasilan komperhensif lainnya. 
Penyusunan laporan keuangan menjadi hal penting yang harus disusun oleh suatu unit perusahaan. Laporan keuangan yang disusun berfungsi sebagai alat informasi yang menghubungkan perusahaan dengan pihak-pihak yang memiliki kepentingan dengan laporan keuangan perusahaan. Bagi pihak internal laporan keuangan ini dapat berfungsi sebagai media untuk mengukur kinerja keuangan perusahaan dan memantau perkembangan perusahaan. Sedangkan bagi pihak eksternal yang memiliki kepentingan dengan laporan keuangan perusahaan dapat dijadikan sebagai informasi bahan pertimbangan dalam pemberian modal.

Analisis perubahan pendapatan merupakan analisa yang menganalisis setiap pos-pos dilaporan laba-rugi yang secara terperinci sangat penting karena keberhasilan perusahaan dalam jangka panjang akan tergantung pada realisasi keuntungan sehingga mengetahui sebab-sebab perubahan tersebut, baik perubahan yang menguntungkan (kenaikan) maupun perubahan yang tidak menguntungkan (penurunan), sehingga akan dapat diambil kesimpulan dan atau diambil tindakan seperlunya untuk periode-periode berikutnya.

Untuk itu penulis ingin mengetahui bagaimana perubahan pendapatan yang terjadi di PT Telekomunikasi Indonesia Tbk. pada tahun 2017 dan 2018. Apakah perusahaaan tersebut mengalami kenaikan atau penurunan pada kondisi keuangan dalam laporan keuangan sesuai dengan kenyataan yang ada,.

\section{TINJAUAN PUSTAKA}

PT Telekomunikasi Indonesia Tbk dan Anak Perusahaan, merupakan Badan Usaha Milik Negara dan penyedia pelayanan telekomunikasi serta jaringan terbesar di Indonesia. Telkom menyediakan layanan Info Comm, telepon kabel tidak bergerak (Fixed Wireless), layanan telepon seluler, data dan internet, serta jaringan dan interkoneksi, baik secara langsung maupun melalui anak perusahaan (Soetarmiyati 2012).

Adapun faktor yang mendasar yang ingin dituju setiap perusahaan adalah keterbukaanin formasi, keuangan perusahaan dimaksudkan agar setiap pihak diluar perusahaan mengetahui gambaran yang lengkap mengenai prospek dan kinerja perusahaan. Apakah semakin meningkat atau sebaliknya (Noor 2011).

Untuk mengetahui hal tersebut perlu adanya analisis laporan keuangan yang dapat dijadikan sebagai pengambilan keputusan bagi pihak-pihak yang berkepentingan (Sulistyowati 2015). Salah satu analisis laporan keuangan pada analisis perubahan pendapatan yaitu analisis laba kotor dimana laba kotor merupakan alat yang tepat untuk menentukan naik turunya harga jual pada setiap perusahaa (Rispayanto 2013). Laba kotor diperoleh dari penjualan netto dikurangi dengan harga pokok penjualan. Hal ini menunjukkan perubahan laba kotor yang disebabkan dua faktor yaitu faktor penjualan dan faktor harga pokok penjualan. Peyebab unsure perubahan laba kotor yaitu perubahan harga pokok penjualan, perubahan kuantitas produk yang dijual, perubahan harga pokok persatuan, perubahan kuantitas harga pokok penjualan, perubahan komposisi penjualan dan perubahan total kuantitas (Listiadi 2018).

Selisih dalam laba kotor (gross proft) perlu dianalisis untuk mengetahui sebab-sebab selisih yang terjadi, baik perubahan yang menguntungkan (favourable) maupun selisih yang tidak menguntungkan (unfavourable) sehingga akan dapat diambil kesimpulan dan diambil tindakan seperlunya untuk periode - periode berikutnya (Fallis 2013). Dalam hal ini hendaknya laba kotor bernilai besar hal ini guna menutupi biaya-biaya yang harus dikeluarkan oleh perusahaan seperti biaya penjualan, biaya administrasi, biaya pajak penghasilan dan biaya-biaya lainnya (Kurniawan, Kusni, and Cholifah 2018).

Laba merupakan perubahan menuju keadaan yang lebih baik, lebih sehat, lebih sejahtera well being atau better offness ini tidak didefinisikan secara jelas dalam bentuk terminologi yang operasional dan dapat diterapkan dalam perusahaan (Marpaung 2006). Pelaporan laba digunakan untuk memberikan informasi mengenai laba yang mampu dihasilkan oleh perusahaan (Ardi 2018). 


\section{METODE PENELITIAN}

a. Perubahan harga jual (Sales Price Variance), yaitu adanya perubahan antara harga jual yang sesungguhnya dengan harga jual yang dibudgetkan atau harga jual tahun sebelumnya. Perubahan laba kotor yang disebabkana dan yang perubahan harga jual dapat ditentukan dengan rumus:

(Harga jual menurut realisasi atau yang sesungguhnya - harga jual budget atau tahun sebelumnya) X kuantitas produk yang sesungguhnya dijual.

Atau:

$(\mathrm{Hj} 2-\mathrm{Hj} 1) \mathrm{K} 2$

$\mathrm{Hj} 2$ = Harga jual per satuan produk yang sesungguhnya

$\mathrm{Hj} 1$ = Harga jual per satuan produk yang dibudgetkan atau tahun sebelumnya

$\mathrm{K} 2$ = Kuantitas atau volume produk yang sesungguhnya dijual tahun ini

Apabila $(\mathrm{Hj} 2$ - Hj1) menunjukkan / menghasilkan angka positif berarti ada kenaika nharga yang berarti menunjukkan keadaan yang menguntungkan, sebaliknya bila negative berarti ada penurunan harg jual. dan menunjukkan keadaan yang merugikan.

b. Perubahan kuantitas produk yang dijual (Sales Volume Variance),yaitua dan perbedaan antara kuantitas produk yang direncanakan / tahun sebelumnya dengan kuantitas produk yang sesungguhnya dijual (direalisir). Perubahan laba kotor yang disebabkan oleh perubahankuantitas / volume produk yang dijual dapat ditentukan dengan rumus:

(Kuantitas penjualan yang sesungguhnya - kuantitas penjualan yang dibudgetkan atau tahun sebelumnya) $\mathrm{X}$ harga jual yang dibudgetkan.

Atau:

$$
(\mathrm{K} 2-\mathrm{K} 1) \mathrm{Hj} 1
$$

K2 = Kuantitas penjualan yang sesungguhnya direalisai tahun ini

$\mathrm{K} 1=$ Kuantitas penjualan yang dibudgetkan atau tahun sebelumnya

$\mathrm{Hj} 1=$ Harga jual per satuan produk yang dibudgetkan atau tahun

Bila (K2 - K1) menghasilkan angka positip menunjukkan bahwa kuantitasp roduk yang sesungguhnya dijual lebih besar dari pada yang direncanakan, hal ini menunjukkan keadaan yang menguntungkan atau bagian penjualan bekerja lebih baik; sebaliknya bila menghasilkan angka negative berarti penjualan turun dan menunjukkan keadaan yang merugikan.

c. Perubahan harga pokok penjualan per satuan produk (Cost Price Variance), yaitu adanya perbedaan antara harga pokok penjualan per satuan produk (Unit Cost) menurut budget / tahun sebelumnya dengan harga pokok yang sesungguhnya. Untuk menentukan besarya perubahan laba kotor yang disebabkana dan perubahan harga pokok penjualan per satuan produk dapat ditentukan dengan rumus:

(Harga pokok penjualan yang sesungguhnya - harga pokok penjualan yang dibudgetkan atau tahun sebelumnya) X kuantitas produk yang dijual. Sesungguhnya.

Atau:

(HPP2 - HPP1) K2

HPP2= Harga pokok penjualan yang sesungguhnya

HPP1 = Harga pokok penjualan menurut budge $t /$ tahun sebelumnya

$\mathrm{K} 2$ = Kuantitas produk yang sesungguhnya di jual

Apabila (HPP2 - HPP1) menghasilkan angka positip berarti HPP mengalami kenaikan, kenaikan dalam sector biaya menunjukkan keadaan yang merugikan, sebaliknya bila hasilnya negatipf berarti biaya mengalami penurunan yang berarti pula menunjukkan keadaan yang menguntungkan. 
d. Perubahan kuantitas harga pokok penjualan (Cost Volume Variance) yaitu adanya perubahan harga pokok penjualan karena adanya perubahan kuantitas / volume yang dijual atau yang diproduksi. Rumus untuk menentukan besarnya perubahan laba bruto karena perubahan kuantitas harga pokok penjualan adalah:

(Kuantitas yang sesungguhnya - kuantitas menurut (budget atau tahun sebelumnya) X harga pokok menurut budget atau tahun sebelunnya. Atau penggunaan rumus lain sebagai berikut:

\section{(K2-K1) HPP1}

$\mathrm{K} 2=$ Kuantitas produk yang sesungguhnya dijual / dihasilkan

$\mathrm{K} 1=$ Kuantitas produk menurut budget / tahun sebelumnya

HPP1= Harga pokok penjualan per satuan barang menurut budget

Apa bila (K2 - K1) menghasilkan angka positif berarti kuantitas yang dijual / diproduksi bertambah (mengalami kenaikan), apabila kuantitas bertambah maka harga pokok penjualan akan mengalami kenaikan pula dan bertambahnya harga poko penjualan menunjukkan keadaan yang tidak menguntungkan (merugikan). Sebaliknya bila hasilnya negative berarti ada penurunan biaya dan menunjukkan keadaan yang menguntungkan.(Amelia N, Machfiroh S. I, 2018).

\section{PEMBAHASAN}

Hasil analisis laporan keuangan perusahaan PT Telekomunikasi Indonesia menggunakana analisis perubahan pendapatan dengan analisis laba kotor dimana perusahaan yang penulis menggunakan laporan laba-rugi selama dua tahunyang dapat dilihat pada tabel 1 .

Tabel1 Data Laporan Laba-Rugi PT Telekomunikasi Indonesia Tbk.

\begin{tabular}{|c|c|c|c|c|c|c|}
\hline Keterangan & \multicolumn{2}{|r|}{2017} & & 2018 & \multicolumn{2}{|c|}{ Selisih } \\
\hline Penjualan netto & \multirow{2}{*}{\multicolumn{2}{|c|}{$\begin{array}{l}\mathrm{Rp} 1.716 .193 .536 \\
\mathrm{Rp} 1.142 .228 .922\end{array}$}} & & 865.895 .328 & \multicolumn{2}{|c|}{ Rp 149.701.792 } \\
\hline Harga Pokok Penjualan & & & $\mathrm{Rp}$ & 336.689 .497 & \multirow{2}{*}{\multicolumn{2}{|c|}{$\begin{array}{l}\operatorname{Rp} 194.460 .575 \\
\operatorname{Rp}(44.758 .783)\end{array}$}} \\
\hline Laba kotor & & 573.964 .614 & $\mathrm{Rp}$ & 529.205 .831 & & \\
\hline Kuantitas yang dijual & \multicolumn{2}{|r|}{318.353} & & 287.911 & \multicolumn{2}{|c|}{$(30.442)$} \\
\hline Harga Jual per satuan & $\mathrm{Rp}$ & $5.390,85$ & $\mathrm{R}_{1}$ & $6.480,81$ & $\mathrm{Rp}$ & $1.089,96$ \\
\hline Harga pokok per satuan & $\mathrm{Rp}$ & $3.587,93$ & $\mathrm{Rp}$ & $4.642,72$ & $\mathrm{Rp}$ & $1.054,79$ \\
\hline
\end{tabular}

Pada tabel 1 diperlihatkan Data laporan laba rugi tahun 2017 yang telah dibandingkan dengan data tahun 2018 menunjukan adanya kenaikan dalam penjualan netto sebesar Rp 149.701 .792 dan kenaikan harga pokok penjualan sebesar Rp 194.460.575, sehingga terjadi penurunan laba kotor pada tahun 2018 sebesar $\mathrm{Rp}$ 44.758.783. Hal ini terjadi karena harga pokok produk yang mengalami kenaikan ditahun 2018 sebesar Rp 1.054,79 dari yang awalnya hanya $\mathrm{Rp} \mathrm{3.587,93}$ menjadi $\mathrm{Rp} 4.642,72$ sehingga harga jual produk yang awalnya $\mathrm{Rp} 5.390,85$ juga harus mengalami kenaikan sebesar Rp 1.089,96 menjadi Rp 6.480,81 per satuan produk.

Tabel 2 Laporan Perubahan Laba Kotor

\begin{tabular}{|l|l|lc|}
\hline Sebab Perubahan Laba Kotor & \multicolumn{1}{|c|}{ A } & \multicolumn{1}{c|}{ B } \\
\hline Perubahan harga jual & $\mathrm{Rp} 313.810 .073$ & $\mathrm{Rp}$ & 313.810 .073 \\
\hline Perubahan kuantitas penjualan & $\mathrm{Rp} \quad(164.108 .281)$ & $\mathrm{Rp}$ & $(164.108 .281)$ \\
\hline $\begin{array}{l}\text { Perubahan harga pokok penjualan } \\
\text { per satuan }\end{array}$ & $\mathrm{Rp} 303.684 .402$ & $\mathrm{Rp}$ & 303.684 .402 \\
$\begin{array}{l}\text { Perubahan kuantitas harga pokok } \\
\text { penjualan }\end{array}$ & $\mathrm{Rp} \quad(109.223 .827)$ & $\mathrm{Rp}$ & $(109.223 .827)$ \\
\hline
\end{tabular}


Pada tabel 2 memperlihatkan bahwa perubahan laba kotor yang disebabkan oleh faktor penjualan berupa perubahan harga jual menghasilkan angka positif yang berarti menunjukkan keadaan yang menguntungkan sebesar Rp. 313.810.073, sedangkan perubahan laba kotor yang disebabkan oleh harga pokok penjualan berupa perubahan harga pokok penjualan per satuan produk menghasilkan angka positif berarti HPP mengalami kenaikan, kenaikan dalam sektor biaya menunjukkan keadaan yang merugikan sebesar Rp. 303.684.402.

Perubahan kuantitas penjualan menghasilkan angka negatif yang berarti kuantitas produk yang sesungguhnya dijual lebih kecil dari pada yang direncanakan, hal ini menunjukkan keadaan yang merugikan sebesar Rp. 164.108.281 dan perubahan kuantitas harga pokok penjualan menghasilkan angka negatif berarti kuantitas yang dijual/diproduksi berkurang (mengalami penurunan), apabila kuantitas berkurang maka harga pokok penjualan akan mengalami penurunan pula dan berkurangnya harga pokok penjualan menunjukkan keadaan yang menguntungkan sebesarRp. 109.223.827.

Tabel 3 Laporan Keuangan

\begin{tabular}{|c|c|c|}
\hline \multicolumn{3}{|l|}{ Laporan Keuangan } \\
\hline \multicolumn{3}{|l|}{ Kenaikan penjualan yang disebabkan } \\
\hline Kenaikan harga jual & $\mathrm{Rp}$ & 313.810 .073 \\
\hline \multirow{2}{*}{ Kenaikan Kuantitas penjualan } & $\mathrm{Rp}$ & $(164.108 .281)$ \\
\hline & $\mathrm{Rp}$ & 149.701 .792 \\
\hline \multicolumn{3}{|l|}{ Kenaikan harga pokok penjualan disebabkan : } \\
\hline Kenaikan harga pokok per satuan produk & $\mathrm{Rp}$ & 303.684 .402 \\
\hline \multirow[t]{2}{*}{ Kenaikan Kuantitas harga pokok penjualan } & $\mathrm{Rp}$ & $(109.223 .827)$ \\
\hline & $\mathrm{Rp}$ & 194.460 .575 \\
\hline 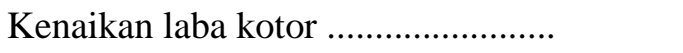 & $\mathrm{Rp}$ & $(44.758 .783)$ \\
\hline
\end{tabular}

Pada tabel 3, berdasarkan Laporan Keuangan terlihat bahwa PT Telekomunikasi Indonesia Tbk. telah mengalami kerugian sebesar Rp. 44.758 .783 karena perubahan laba kotor yang disebabkan oleh faktor kenaikan harga pokok produk yang di ikuti juga dengan kenaikan harga penjualan sehingga berakibat penurunan penjualan produk.

\section{KESIMPULAN}

Berdasarkan hasil penelitian, dari beberapa data laporan keuangan tahun 2017 dan 2018 pada PT Telekomunikasi Indonesia Tbk. menunjukan adanya penurunan nilai laba kotor yang di dapat pada tahun 2018 padahal terjadi kenaikan dalam nilai penjualan netto dan nilai kenaikan harga pokok penjualan,. Penurunan laba kotor ini disebabkan oleh faktor faktor kenaikan harga pokok produk yang di ikuti juga dengan kenaikan harga penjualan sehingga berakibat penurunan penjualan produk. Perubahan kuantitas penjualan menghasilkan angka negatif yang berarti kuantitas produk yang sesungguhnya dijual lebih kecil dari pada yang direncanakan, hal ini menunjukkan keadaan yang merugikan.

\section{DAFTAR PUSTAKA}

https://www.idx.co.id/perusahaan-tercatat/laporan-keuangan-dan-tahunan/

Ardi, Muhammad. 2018. "Analisis Laba Kotor Sebagai Alat Untuk Menentukan Naik Turunnya Harga Jual Pada Qmart Superstore Kota Gorontalo Muhammad Ardi.” : 124-46.

Fallis, A.G. 2013. “済無No Title No Title.” Journal of Chemical Information and Modeling 53(9): 1689-99.

Kurniawan, Ricky, Hidayanti Kusni, and Cholifah. 2018. "Pengaruh Penjualan Dan Harga Pokok Penjualan Terhadap Perubahan Laba Kotor Pada Pt. Indocement Tunggal Prakarsa, Tbk." : 63. 
Listiadi, A. 2018. “Jbima (Jurnal Bisnis Dan Manajemen).” Jurnal Bisnis dan Manajemen 6(2): 92-114.

Marpaung, Elyzabet Indrawati. 2006. "Kemampuan Laba, Piutang, Persediaan Biaya Administrasi Dan Penjualan, Dan Rasio Laba Kotor Terhadap Penjualan Dalam Memprediksi Laba Perusahaan." Jurnal Akuntansi 5(2): 1-16.

Noor, Akhmad Syafrudin. 2011. "April 2011, Volume 12 Nomor 1.” Analisis Falktor-Faktor Yang Mempengaruhi Kinerja Keuangan Perusahaan Telekomunikasi Yang Go Public Di Bursa Efek Indonesia 12(April): 45-50.

Rispayanto, Shofiahilmy. 2013. "Pengaruh Laba Kotor, Laba Operasi, Laba Bersih, Dan Arus Kas Operasi Masa Mendatang (Studi Empiris Pada Perusahaan Manufaktur Yang Terdaftar Di BEI)." Jurnal Akuntansi 1(3): 1-29. http://ejournal.unp.ac.id.

Soetarmiyati, Nani. 2012. "Nani Soetarmiyati JMK, Vol. 10, No. 1, Maret 2012." 10(1).

Sulistyowati, Nur Wahyuning. 2015. "Analisis Laporan Keuangan Sebagai Alat Untuk Menilai Kinerja Keuangan Pt Pelabuhan Indonesia Iii Surabaya." Assets: Jurnal Akuntansi dan Pendidikan 4(2): 125.

\section{Biodata Penulis}

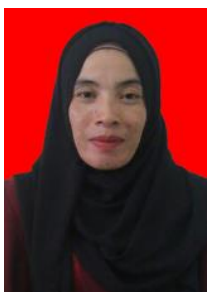

Eni Suasri, lahir di Benua Tengah, 10 Maret 1977. Menempuh pendidikan S1 Akuntansi di Sekolah Tinggi Ilmu Ekonami Nasional Banjarmasin dan lulus tahun 2004 kemudian melanjutkan S2 Manajemen di Sekolah Tinggi Ilmu Ekonomi Pancasetia Banjarmasin dan lulus pada tahun 2014. Pada tahun 2010 sampai dengan tahun 2018 penulis berprofesi sebagai staff keuangan di Politeknik Negeri Tanah Laut. Dan sejak tahun 2018 sampai sekarang penulis kemudian menjadi dosen tetap di Program Studi Akuntansi Politeknik Negeri Tanah Laut.

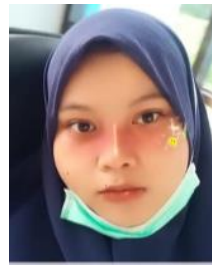

Dahlia, lahir di Pelaihari, 14 Februari 1997. Dahlia menempuh pendidikan Diploma III Akuntansi di salah satu perguruan tinggi di Kalimantan Selatan yaitu di Politeknik Negeri Tanah Laut. Saat ini Dahlia masih tercatat sebagai mahasiswa tingkat akhir di program studi DIII Akuntansi Politeknik Negeri Tanah Laut. 